Reprinted with permission from: Weed Science. May 1984. 32(3):348-352.

Published and copyrighted by: Weed Science Society of America. http://www.wssa.net

\title{
Utilization of leafy spurge (Euphorbia esula) by sheep ${ }^{1}$
}

\author{
BARBARA K. LANDGRAF, PETER K. FAY, and KRIS M. HAVSTAD \\ Landgraf is Res. Asst. and Asst. Prof., and Fay is Assoc. Prof., Dep. of Plant and Soil Sci., and Havstad is Asst. Prof. \\ Dep. of Animal and Range Sci., Montana State Univ., Bozeman, MT 59717.
}

\begin{abstract}
:
The forage selection and grazing behavior of sheep in leafy spurge (Euphorbia esula L. \#2 EPHES)-infested pastures was examined in a 3-month grazing study conducted during the summer, 1981. No definite preference for or avoidance of leafy spurge was detected. An initial 1- to 3-week avoidance was observed, followed by a steady increase in leafy spurge consumption. A maximum intake of 40 to $50 \%$ of the diet per animal was observed. Weight gain by ewes in pastures infested with leafy spurge was not significantly different from weight gain by ewes in pastures free of leafy spurge. Results from these studies indicate that leafy spurge may be classified as a forage for sheep. Sheep will consume a significant amount of vegetation while suffering neither harmful internal effects nor a significant loss of body weight. Sheep can be considered an effective biological control agent for leafy spurge.
\end{abstract}

\section{Additional index words:}

Biological weed control, EPHES.

\section{Introduction}

Leafy spurge is a perennial noxious weed that infests over 1 million ha in North America (21). Montana has more than 200,000 ha of leafy spurge-infested land, most of

\footnotetext{
${ }^{1}$ Published with the approval of the Director, Montana Agric. Exp. Stn., Bozeman, as journal Article No. J-1405. Received for publication April 25, 1983, and in revised form October 26, 1983.

${ }^{2}$ Letters following this \# symbol are a WSSA-approved computer code from Important Weeds of the World, 3rd ed., 1983. Available from WSSA, 309 West Clark St., Champaign, IL 61820.
} 
which is found on rangelands (21). The presence of leafy spurge has reduced the grazing capacity of rangeland up to $75 \%$ (22).

Ranchers in Montana have been using sheep to control leafy spurge for more than 40 years; however, little scientific research on the utilization of leafy spurge by sheep has been reported. Johnston and Peake (15) examined the effect of selective grazing by sheep on pasture containing a mixture of leafy spurge and crested wheatgrass [Agropyron cristatum (L.) Gaertn.]. The leafy spurge infestation was reduced $98 \%$ after being grazed seasonally from May to September by ewes during five successive seasons.

Helgeson and Thompson (14) grazed sheep on 0.45-ha pastures infested with leafy spurge that was either mowed or left unmowed. After 2 years of grazing the number of leafy spurge stems was reduced 68 and $31 \%$ in the mowed and unmowed pastures, respectively. L. O. Baker ${ }^{3}$ found that grazing of leafy spurge reduced the infestation $34 \%$ from the initial level and resulted in a 10\% increase in grass density after 6 years.

Wood (24) reported several cases in which producers used sheep to control leafy spurge after 2 to 4 years of continuous grazing. Muenscher (19) stated that pastures with large infestations of leafy spurge should be seeded with grass and grazed closely with sheep for at least 3 or more years. Bibbey (3) reported that sheep effectively controlled leafy spurge and nearly eradicated the plant if grazing continued over a period of years.

There is disagreement in the literature concerning the effect of leafy spurge on sheep. Muenscher (19), Christensen et al. (5), Wood (24), and Baker ${ }^{4}$ state that sheep suffered no deleterious effects as a result of consuming leafy spurge. Bakke (1) stated that neither sheep nor cattle would eat leafy spurge because of its acrid latex. He reported that sheep ate leafy spurge only in the absence of other forage, although no harmful effects to the sheep were noted after consumption of the weed. Helgeson and Thompson (14) found that sheep suffered no ill effects from leafy spurge with the exception of several lambs that scoured.

The deaths of an unknown number of sheep were attributed to poisoning as a result of consuming relatively mature leafy spurge plants (15). No losses were reported when sheep were placed in the same pastures at an earlier date. Undocumented postmortem examinations indicated that poisoning by leafy spurge was responsible for the losses.

Bartik and Piskac (2) stated that leafy spurge and other closely related species produce a poisonous white latex that affects almost all animal species. They found that drying did not eliminate toxicity.

Farnsworth et al. $(10,11)$ conducted a preliminary phytochemical and biological evaluation of leafy spurge. A concentrated extract of leafy spurge produced only a weak depression of the central nervous system in mice. Tertiary and quaternary alkaloids, considered to be the toxic compounds in many poisonous plants (16), were present in the aerial parts of leafy spurge.

\footnotetext{
${ }^{3}$ Baker, L. O. 1981. Personal communication. Dep. of Plant and Soil Sci., Montana State Univ., Bozeman.

${ }^{4}$ personal communication. Dep. of Plant and Soil Sci., Montana State Univ., Bozeman.
}

Page 2 of 10 
Given the variations and contradictions presented in the literature on leafy spurge, the objectives of this study were to: a) quantify consumption of leafy spurge by sheep in a free-choice pasture; b) determine diet selection differences between sheep in pastures containing different densities of leafy spurge; c) determine whether preconditioning sheep in confinement with pure leafy spurge hay would influence subsequent diet selection of the free-ranging ewe; and d) determine whether leafy spurge hay has deleterious internal or external effects on sheep.

\section{Materials and methods}

Winter feeding experiment. A 12-week feeding trial was conducted at the Montana State Agric. Exp. Stn., Fort Ellis, from January until April 1981. Fifteen ewes of various ages and breeds were randomly selected from the flock located at the Montana State Agric. Exp. Stn., Red Bluff, and separated into three groups containing five animals each. The groups were maintained separately in 4- by 5-m pens with separate feeders and automatic drinking fountains. The pure leafy spurge hay, donated by the N-Bar Ranch, Grass Range, MT, was cut and baled in mid-July 1980 when the leafy spurge plants were in the bloom stage of growth. Meadowgrass hay for the control ration, consisting of orchardgrass (Dactylus glomerata L.) and timothy (Phleum pratense L.), was obtained from the Montana Agric. Exp. Stn., Fort Ellis. The hay was cut in the seed set phenological growth stage in mid-July, 1980.

All groups of sheep were fed $1.82 \mathrm{~kg}$ of hay per head per day based on National Research Council (20) nutrient requirements for mature nonlactating ewes $(2.4 \%$ of body weight per day as dry matter intake). Group I, the control, was fed only grass hay. Group II was initially fed grass hay containing $0.15 \mathrm{~kg}$ leafy spurge hay per day. At weekly intervals, the amount of leafy spurge hay was increased by $0.15 \mathrm{~kg}$ with an equivalent decrease in grass hay. The hay ration reached $100 \%$ leafy spurge hay after 10 weeks. Animals in Group III were initially fed $0.94 \mathrm{~kg}$ leafy spurge hay per day. The amount of leafy spurge hay was increased $0.22 \mathrm{~kg}$ per day. The ration reached $1.82 \mathrm{~kg}$ of leafy spurge hay per day after 5 days.

Blood samples were collected every 21 days from each animal during the experiment in the event we needed to monitor internal physiology (17). Two blood samples were collected from the jugular vein using an integrated serum separator tube ${ }^{5}$ and a liquid EDTA tube $^{6}$. Nineteen individual tests were performed on blood from each animal by the Montana State Univ. Vet. Res. Lab., on samples which were taken prior to and immediately following the winter feeding experiment. The blood samples taken during the experiment were not analyzed.

Field grazing study. A field grazing study was conducted near the Little Belt Mountains in central Montana on the Baxter Ranch located $10 \mathrm{~km}$ south of Geyser, MT. Terrain varied from flatland to rolling hills in the foothill and mountain geographic region of

\footnotetext{
${ }^{5}$ Corvac, Sherwood Medical, St. Louis, MO.
}

${ }^{6}$ Venoject, Kimble-Terumo, Elkton, MD. 
the state. The 27 -ha experimental area was a silty clay range site in a 38 - to 48 -cm precipitation zone.

Pastures were constructed using a natural leafy spurge infestation gradient. The rectangular area was divided into six 265 - by $152-\mathrm{m}$ pastures ( $4.05 \mathrm{ha})$ arranged in a pairedplot design. The north pasture of each pair was sprayed with $2 \mathrm{~kg}$ ae/ha 2,4-D ester [the butyl ester of (2,4-dichlorophenoxy)acetic acid] in $167 \mathrm{~L} /$ ha of water on May 18, 1981, with a sprayer mounted on a pickup truck. This treatment eliminated aerial growth of leafy spurge for the entire period of the experiment from May until September 1981.

Three line transects were established in each pasture along which were placed 25 quadrants $(50$ by $220 \mathrm{~cm}$ ) to estimate canopy cover and to determine plant species composition (8).

Esophageal fistula collections. Thirty-eight mature ewes of various fine-wool breeds were used in the experiment. Esophageal fistulas (12) were placed in 14 ewes between May 5 and 8, 1981, using a cannula design from Denny (9). Two of the fistulated animals were maintained as replacement ewes.

Four fistulated sheep were placed in each infested, unsprayed pasture with two unfistulated ewes to produce a stocking rate of 1.3 ha per animal unit month (AUM). Six unfistulated ewes were placed in each sprayed pasture on June 15, 1981. Two of the four fistulated sheep in each infested pasture had received leafy spurge during the previous winter feeding trial. None of the ewes in the control pasture had previous exposure to leafy spurge. Individual animals were weighed once a week using a portable platform scale.

Forage samples were collected from each fistulated animal in a screen-bottomed canvas collection bag once every 10 to 12 days. Samples were collected from a single group per sampling day. On the morning of collection, the animals were placed in a confinement pen located inside their respective pastures. Cannulae were replaced with collection bags and the sheep were allowed to graze normally for 20 to 25 minutes. The collection bags were removed and the cannulae were replaced. Individual samples were frozen immediately for future analysis. These samples were later analyzed for percent forb, grass, shrub, and leafy spurge by the microscopic point technique (13).

\section{Results and discussion}

Winter feeding experiment. Ewes fed grass hay (group I) gained weight, while those fed increasing quantities of leafy spurge (group II) or leafy spurge entirely (group III) lost weight during the experiment (Table 1). Despite the significant loss of weight in animals consuming leafy spurge, the loss of 2.5 and $4.2 \mathrm{~kg}$ (3.5 to $7.0 \%$ of body weight) per animal is not unusual for mature unbred ewes over a 3 -month period during the winter (4, $6)$. Hay containing leafy spurge was palatable to sheep and did not have any visual deleterious effects on the animals. 
Table 1. Weight gain or loss for three groups of sheep fed different hay rations during a 12week feeding experiment.

\begin{tabular}{clc}
\hline Group & \multicolumn{1}{c}{ Hay ration } & Weight change $^{\mathrm{a}}$ \\
\hline & & $(\mathrm{kg})$ \\
I & Control (grass hay only) & $+2.5 \mathrm{a}$ \\
II & Increasing level of leafy spurge & $-2.5 \mathrm{~b}$ \\
III & Leafy spurge hay only & $-4.2 \mathrm{c}$ \\
\hline
\end{tabular}

${ }^{\mathrm{a}}$ Means followed by a different letter are significantly different at $\mathrm{P}=0.05$ according to the LSD test of significance.

Blood analysis. Blood analyses indicated that the sheep suffered no harmful internal physiological effects from consumption of leafy spurge hay (Table 2). There were differences in the total protein of blood between groups but all values were within the normal range for sheep. Groups I, II, and III averaged $7.0 \pm 0.3,6.6 \pm 0.3$, or $6.3 \pm 0.3 \mathrm{~g}$ of protein/0.1 L, respectively, and all means were significantly different $(\mathrm{P} \geq 05)$. There appeared to be a relationship between the amount of leafy spurge hay in the diet and the protein level in the blood. This observation may have been due to a lower protein content in the leafy spurge hay. Leafy spurge hay, at $9 \%$ crude protein, contained $20 \%$ less crude protein than the grass hay. This protein difference probably caused the difference in weight gain or loss among the test groups.

Glucose, cholesterol, and bilirubin (Table 2) values were within normal ranges. There was no difference in albumin and globulin levels between groups and therefore no damage occurred to the liver.

Total protein, creatinine, and chloride levels were within the normal range for sheep (Table 2). Magnesium levels were in the normal range for sheep with no differences between groups, indicating that consumption of leafy spurge did not result in kidney damage.

No abnormal values were detected for red blood cell (RBC). White blood cell (WBC), hemoglobin (HGB), hematocrit (HCT), and mean corpuscular volume (MCV) (Table 2). Blood analyses for calcium, phosphorus, sodium, and potassium (Table 2) indicated all values were in the normal ranges for sheep.

Creatinine pyrophosphokinase $(\mathrm{CPK})$ is routinely used to measure internal muscle deterioration. While normal levels for CPK have not been established, there were no differences in CPK levels between groups (Table 2). 
Table 2. Results of blood analysis performed at the conclusion of the winter feeding experiment on three groups of mature ewes receiving different hay rations.

\begin{tabular}{|c|c|c|c|c|c|}
\hline \multirow[b]{2}{*}{ Blood test (units) } & \multirow[b]{2}{*}{ Test indicative of } & \multirow[b]{2}{*}{$\begin{array}{c}\text { Normal } \\
\text { ovine values }\end{array}$} & & \multicolumn{2}{|c|}{ Group (hay ration)a } \\
\hline & & & Grass only & $\begin{array}{l}\text { Increasing } \\
\text { level leafy } \\
\text { spurge }\end{array}$ & $\begin{array}{l}\text { Leafy } \\
\text { spurge } \\
\text { only }\end{array}$ \\
\hline Glucose (mg/dl) & Energy balance & $30-65$ & $58 \mathrm{a}$ & $63 \mathrm{a}$ & $66 \mathrm{a}$ \\
\hline Cholesterol (mg/dl) & $\begin{array}{l}\text { Metabolized steroids, liver, } \\
\text { thyroid condition }\end{array}$ & $52-76$ & $54 \mathrm{a}$ & $66 \mathrm{~b}$ & $50 \mathrm{a}$ \\
\hline Bilirubin (mg/dl) & $\begin{array}{l}\text { Liver, breakdown of red } \\
\text { blood cells }\end{array}$ & $0-0.39$ & $0.09 \mathrm{a}$ & $0.27 \mathrm{a}$ & $0.24 \mathrm{a}$ \\
\hline $\operatorname{Albumin}(\mathrm{g} / \mathrm{dl})$ & $\begin{array}{l}\text { Liver or gastrointestinal } \\
\text { condition }\end{array}$ & $\mathrm{NA}^{\mathrm{b}}$ & $3.9 \mathrm{a}$ & $3.7 \mathrm{a}$ & $3.6 \mathrm{a}$ \\
\hline Globulin $(\mathrm{g} / \mathrm{dl})$ & $\begin{array}{l}\text { Immuno state, gastrointes- } \\
\text { tinal, liver condition }\end{array}$ & NA & $3.3 \mathrm{a}$ & $3.2 \mathrm{a}$ & $2.9 \mathrm{a}$ \\
\hline Creatinine (mg/dl) & Kidney condition & $1.2-2.0$ & $1.3 \mathrm{a}$ & $1.4 \mathrm{a}$ & $1.3 \mathrm{a}$ \\
\hline Chloride (mEq/1) & $\begin{array}{l}\text { Chloride levels, gastroin- } \\
\text { testinal blockage, kidney } \\
\text { condition }\end{array}$ & $98-109$ & $102 \mathrm{a}$ & $100 \mathrm{~b}$ & $101 \mathrm{~b}$ \\
\hline Magnesium (mg/dl) & Magnesium metabolism & $1.7-2.1$ & $1.8 \mathrm{a}$ & $1.9 \mathrm{a}$ & $1.8 \mathrm{a}$ \\
\hline $\begin{array}{l}\text { No. red blood cells } \\
\qquad\left(\times 10^{6} / \mathrm{mm}^{3}\right)\end{array}$ & $\begin{array}{l}\text { Red blood cell count, } \\
\text { anemia problems }\end{array}$ & NA & $10.7 \mathrm{a}$ & $10.6 \mathrm{a}$ & $9.9 \mathrm{~b}$ \\
\hline $\begin{array}{l}\text { No. white blood cells } \\
\qquad\left(\times 10^{2} / \mathrm{mm}^{3}\right)\end{array}$ & $\begin{array}{l}\text { White blood cell count, } \\
\text { illness }\end{array}$ & NA & $6.5 \mathrm{a}$ & $6.6 \mathrm{a}$ & $5.6 \mathrm{a}$ \\
\hline Hemoglobin (g/dl) & Protein respiratory pigment & NA & $12.8 \mathrm{a}$ & $12.0 \mathrm{a}$ & $11.8 \mathrm{a}$ \\
\hline Hematocrit (\%) & $\begin{array}{l}\% \text { red blood cell in total } \\
\text { blood count }\end{array}$ & NA & $34.6 \mathrm{a}$ & $32.8 \mathrm{~b}$ & $31.7 \mathrm{~b}$ \\
\hline $\begin{array}{l}\text { Mean corpuscular vol- } \\
\text { ume }\left(\mu^{3}\right)\end{array}$ & $\begin{array}{l}\text { Nondeficiency, size of red } \\
\text { blood cells }\end{array}$ & NA & $32.6 \mathrm{a}$ & $31.0 \mathrm{a}$ & $32.0 \mathrm{a}$ \\
\hline Calcium (mg/dl) & Calcium metabolism & 9.0 & $9.0 \mathrm{a}$ & $9.2 \mathrm{a}$ & $9.0 \mathrm{a}$ \\
\hline Phosphorus (mg/dl) & Phosphorus metabolism & 4.0 & $5.6 \mathrm{a}$ & $6.5 \mathrm{a}$ & $6.2 \mathrm{a}$ \\
\hline Sodium $(\mathrm{mEq} / \mathrm{L})$ & Sodium levels & $146-161$ & $147 \mathrm{a}$ & $148 \mathrm{a}$ & $147 \mathrm{a}$ \\
\hline Potassium (mEq/L) & Potassium metabolism & $4-8$ & $4.5 \mathrm{a}$ & $4.7 \mathrm{~b}$ & $4.7 \mathrm{~b}$ \\
\hline $\begin{array}{l}\text { Creatinine pyrophos- } \\
\text { phokinase }(\mathrm{I} \mu / \mathrm{L})\end{array}$ & $\begin{array}{l}\text { Skeletal or cardiac muscle } \\
\text { deterioration }\end{array}$ & NA & $33 a$ & $35 \mathrm{a}$ & $16 \mathrm{a}$ \\
\hline $\begin{array}{l}\text { Lactate dehydrogenase } \\
\qquad(\mathrm{I} \mu / \mathrm{L})\end{array}$ & General tissue condition & NA & $226 \mathrm{a}$ & $247 \mathrm{~b}$ & $217 \mathrm{a}$ \\
\hline
\end{tabular}

Field grazing study. All six pastures were dominated by grass species that ranged from $50 \%$ (in the heaviest infested pasture) to $100 \%$ composition (in the herbicide-treated pastures). The percent leafy spurge composition was 41,24 , and $19 \%$ in the heavy, moderate, and lightly infested pastures, respectively. Composition of leafy spurge and grass species was inversely related. The stocking rate (1.3 ha/AUM) was low for all pastures, and less than half of the available forage was utilized during the grazing season. The grass component in all three infested pastures was not fully utilized at any period during the study; therefore, the animals were not forced to consume leafy spurge. 
Weight gain by ewes in pastures infested with leafy spurge was not significantly different from changes observed in ewes in herbicide-treated pastures (data are not presented). There were no differences in weight gain among ewes in any of the three infested pastures (data not presented).

Table 3. The average percent composition of extrusa samples from fistulas from mature ewes grazing during summer in pastures that had either 19\% (light), $24 \%$ (moderate), or $41 \%$ (heavy) levels of leafy spurge.

\begin{tabular}{ccccc}
\hline Animal group & \multicolumn{4}{c}{ Composition of grazing sample $^{\mathrm{a}}$} \\
\cline { 2 - 4 } (leafy spurge infestation) & Leafy spurge & Grass & Forb & Shrub \\
\hline & $24 \mathrm{ab}$ & $39 \mathrm{c}$ & $29 \mathrm{a}$ & $8 \mathrm{a}$ \\
I (light) & $28 \mathrm{~b}$ & $27 \mathrm{a}$ & $35 \mathrm{~b}$ & $9 \mathrm{ab}$ \\
II (moderate) & $20 \mathrm{a}$ & $34 \mathrm{~b}$ & $35 \mathrm{~b}$ & $11 \mathrm{~b}$ \\
III (heavy) &
\end{tabular}

${ }^{a}$ Means within the same column followed by different letters are significantly different at $\mathrm{P}=0.05$ according to the LSD test of significance.

Esophageal fistula collections. Leafy spurge consumption by sheep was low for the first 1 to 3 weeks of the grazing period (Figure 1). Following this initial period, consumption of leafy spurge gradually increased over the following 70 days and eventually reached 40 to $50 \%$ of the daily dry matter intake for each group located on untreated pastures. The samples from fistulated ewes on the moderately infested pasture (Group II) contained an average of $28 \%$ leafy spurge over the entire field study (Table 3 ). Animals grazing the light and heavily infested pastures consumed overall an average of 24 and $20 \%$ leafy spurge, respectively, of their daily intake. None of the ewes on sprayed pastures were fistulated, so the dietary fluctuations cannot be compared among sheep on pastures without leafy spurge.

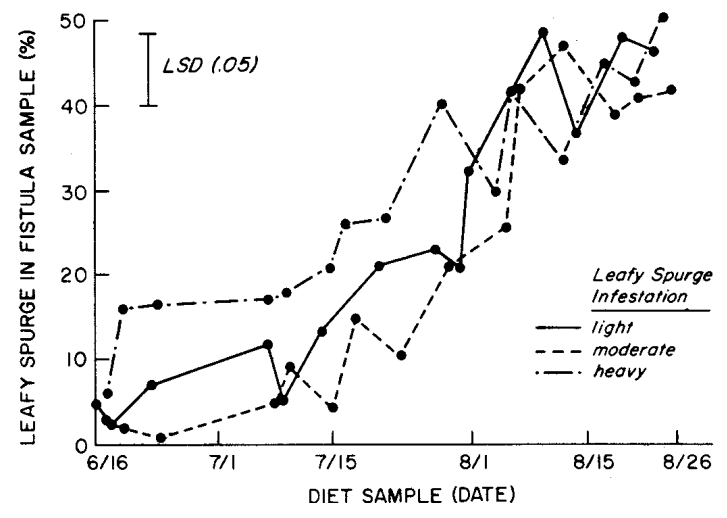

Figure 1. Changes in percent leafy spurge composition with time in diets of mature ewes grazing pastures that contained $19 \%$ (light), $24 \%$ (moderate), or $41 \%$ (heavy) composition of leafy spurge. Extrusa samples from fistula bags were analyzed for percentage leafy spurge using the point technique. 
A shift in forage consumption was observed in fistulated groups in all treatments during the grazing period. As the amount of leafy spurge in the diet increased, the consumption of the grass and forb components decreased (Figure 2). Shifts in forage consumption are not uncommon. Cook and Harris (6) and Cook et al. (7) found that sheep diets were composed largely of grass in early summer and mostly forbs in late summer, since a major component of animal preference is green leaf material (23). Shifts in forage selection by sheep may reflect the availability of succulent, green leafy spurge plant material.

Ewes previously fed on leafy spurge hay did not show a tendency to consume more leafy spurge in the pastures than ewes without previous feeding exposure. It appears that preconditioning sheep with leafy spurge hay did not significantly increase their initial or total consumption of the plant when placed in a free-choice grazing situation. McClymont (18) reported that social factors such as grazing in close association may modify intake and alter grazing behavior.

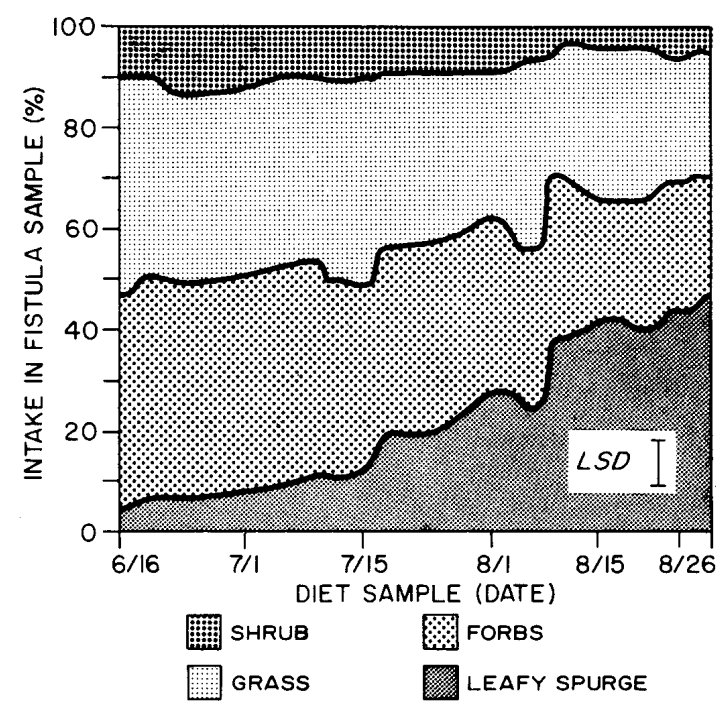

Figure 2. Changes in forage composition of extrusa samples from fistula bags from 12 mature ewes grazing pastures infested with leafy spurge. Contents extrusa samples were analyzed using the point technique.

Daily observations of sheep grazing behavior indicated that all phenological stages of leafy-spurge growth were selected. The inflorescence was usually selected first on mature leafy spurge plants. In many cases the sheep would completely strip the leaves leaving only a bare stem. The sheep normally consumed all the available aboveground vegetation.

Results from these studies quantify the contribution of leafy spurge as a forage in sheep diets. Sheep will consume a significant amount of leafy spurge while suffering neither harmful internal effects nor significant loss of body weight. Sheep can be classified as a biological weed control agent since they utilize leafy spurge. Cattle will not utilize it and chemical control of the plant is not economical on rangeland, so ranchers with large leafy spurge infestations should consider the addition of sheep to their production system 
in order to more fully utilize their rangeland resource. Though sheep may provide an efficient method of utilizing this noxious weed under experimental conditions, management components concerning the use of leafy spurge as a forage under production conditions have not been examined. Future research on leafy spurge use by sheep might include evaluations of this forage within management systems for lactating ewes and subsequent lamb growth.

\section{Literature cited}

1. Bakke, A. L. 1936. Leafy spurge, Euphorbia esula L. Iowa Agric. Exp. Stn. Res. Bull. 198:209-245.

2. Bartik, M. and A. Piskac. 1981. Veterinary Toxicology. Elsevier Scientific Publishing Co., New York. $346 \mathrm{pp}$.

3. Bibbey, R. O. 1952. Beware of leafy spurge. Ontario Dep. Agric. Circ. 125. Ontario, Canada. 5 pp.

4. Bishop, J. P., J. A. Froseth, H. N. Verettoni, and C. H. Noller. 1975. Diet and performance of sheep on rangeland in semiarid Argentina. J. Range Manage. 28:52-55.

5. Christensen, F. W., T. H. Hopper, E. A. Helgeson, and E. J. Thompson. 1938. Leafy spurge as a feed for sheep. Proc. Am. Soc. Anim. Prod. 31:311-316.

6. Cook, C. W. and L. E. Harris. 1968. Nutritional value of seasonal ranges. Utah Agric. Exp. Stn. Bull. $477.55 \mathrm{pp}$.

7. Cook, C. W., L. E. Harris, and M. C. Young. 1967. Botanical and nutritive content of diets of cattle and sheep under single and common use on mountain range. J. Anim. Sci. 26:1169-1174.

8. Daubenmeyer, R. 1959. A canopy coverage method of vegetational analysis. Northwest Sci. 33:43-64.

9. Denny, G. D. 1981. A modification of an esophageal fistula plug that allows low maintenance of freeranging sheep and goats. J. Range Manage. 34:152-153.

10. Farnsworth, N. R., L. K. Henry, G. H., Svoboda, R. N. Blomster, M. J. Yates, and K. L. Euler. 1966. Biological and phytochemical evaluation of plants. I. Biological test procedures and results from two hundred accessions. Lloydia 29:101-122.

11. Farnsworth, N. R., H. Wagner, L. Horhammer, H. P. Horhammer, and 1H.H.S. Fong. 1968. Euphorbia esula L. (Euphorbiaceae) I: Preliminary phytochemical and biological evaluation. J. Pharm. Sci. 57:933-939.

12. Harker, K. W., D. T. Terrell, and G. M. Van Dyne. 1964. Botanical examination of forage from esophageal fistulas in cattle. J. Anim. Sci. 23:465-469.

13. Harris, L. E., G. P. Lofgreen, C. J. Kercher, R. J. Raleigh, and V. R. Bohman. 1977. Techniques of research in range livestock nutrition. Utah Agric. Exp. Stn. Bull. 471. 86 pp.

14. Helgeson, E. A. and E. J. Thompson. 1939. Control of leafy spurge by sheep. North Dakota Agric. Exp. Stn. Bi-monthly Bull. Vol. II:5-9.

15. Johnston, A. and R. W. Peake. 1960. Effect of selective grazing by sheep on the control of leafy spurge (Eupborbia esula L.). J. Range Manage. 13:192-195.

16. Kingsbury, J. M. 1964. Poisonous plants of the United States and Canada. Prentice-Hall, Inc., Englewood Cliffs, NJ 626 pp.

17. Kirk, W. G. and G. K. Davis. 1970. Blood components of range cattle: phosphorus, calcium, hemoglobin, and hematocrit. J. Range Manage. 23:239-243.

Page 9 of 10 
18. McClymont, G. L, 1967. Selectivity and intake in the grazing ruminant. Pages 129-137 in C. G. Code, ed. Handbook of Physiology. Vol. I. Control of Food and Water Intake. Am. Physiol. Soc., Washington, DC.

19. Muenscher, W. C. 1930. Leafy spurge and related weeds. New York State Coll. of Agric. Ext. Bull. 192. $10 \mathrm{pp}$.

20. National Research Council (NRC). 1975. Nutrient requirements of sheep. Nat. Acad. Sci., Comm. Anim. Nut. No. 5. 56 pp.

21. Noble, D. L., P. H. Dunn, and L. A. Andres. 1979. The leafy spurge problem. Pages 8-15 in Proceedings: Leafy spurge symposium. North Dakota State Univ. Coop. Ext. Serv., unnumbered publication.

22. Reilly, W. and K. R. Kaufman. 1979. The social and economic impact of leafy spurge in Montana. Pages 21-24 in Proceedings: Leafy spurge symposium. North Dakota State Univ. Coop. Ext. Serv., unnumbered publication.

23. VanDyne, G. M., N. R. Brodkington, Z. Szocs, J. Ouek, and A. Ribiz. 1980. Large herbivore subsystem. Pages 260-420 in Breymeyer, A. J. and G. M. VanDyne, eds. Grasslands, Systems Analysis and Man. Intern. Biol. Prog. 19. Cambridge Univ. Press.

24. Wood, H. E. 1945. Leafy spurge control. Manitoba Dep. Agric. Pub. No. 200. 9 pp. 